\title{
Obesity and maternal perception: a cross-sectional study of children aged 6 to 8 years in Kuwait
}

Yousif AlRodhan, ${ }^{1}$ Yousef AlAbdeen, ${ }^{1}$ Eisa Saleh, ${ }^{1}$ Naser AlFodari, ${ }^{1}$ Hamad AlSaqer, ${ }^{1}$ Farah Alhumoud ${ }^{1}$ and Lukman Thalib ${ }^{2}$

${ }^{1}$ Faculty of Medicine, Kuwait University, Kuwait. ²Department of Public Health, College of Health Sciences, Qatar University, Doha, Qatar. (Correspondence to: Lukman Thalib: Lthalib@qu.edu.qa)

\begin{abstract}
Background: Childhood obesity is on the increase in the Middle East.

Aims: This study aimed to determine the prevalence of obesity in those aged six to eight years and to investigate maternal perception of child weight.

Methods: A nation-wide study of data on height and weight were obtained from nurses' records, and maternal perceptions were assessed through a self-administered questionnaire. Sample size comprised 2208 individuals with BMI measurements and 1002 with BMI and maternal perception data.

Results: The prevalence of overweight and obese children combined was $40.9 \%$ as per WHO cut-off values and $39.7 \%$ as per Centres for Disease Control and Prevention categorizations. We also found that $77.9 \%$ of overweight and $45.4 \%$ of obese children were perceived by their mothers to have healthy body weights. Additionally, $39.8 \%$ of children with normal weight were also judged by their mothers to be underweight.

Conclusions: An alarmingly high prevalence of childhood obesity among Kuwaiti children, coupled with mothers distorted perception of their child's actual weight status is a serious concern that requires urgent public health intervention. Keywords: obesity, maternal perception, body image, children, Kuwait

Citation: AlRodhan Y; AlAbdeen Y; Saleh E; AlFodari N; AlSaqer H; Alhumoud F et al. Obesity and maternal perception: a cross-sectional study of children aged 6 to 8 years in Kuwait. East Mediterr Health J. 2019;25(7):465-47. https://doi.org/10.26719/emhj.18.060

Received: 01/06/17; accepted: 26/10/17

Copyright (C) World Health Organization (WHO) 2019. Some rights reserved. This work is available under the CC BY-NC-SA 3.0 IGO license (https:// creativecommons.org/licenses/by-nc-sa/3.0/igo).
\end{abstract}

\section{Introduction}

Globally, the number of adults with a body-mass index (BMI) of $25 \mathrm{~kg} / \mathrm{m}^{2}$ or greater has increased between 1980 and 2013 from $28 \cdot 8 \%$ to $36 \cdot 9 \%$ in men, and from $29.8 \%$ to $38.0 \%$ in women (1). This rise is particularly important because obesity has been linked to many illnesses including cardiovascular diseases, diabetes and hypertension. Adults are not the only victims of the rapid increase in the obesity epidemic; children and adolescents are falling victims as well. According to the World Health Organization (WHO), the number of overweight or obese infants and young children under the age of five years increased from 32 million globally in 1990 to 42 million in 2013 (2).

Childhood obesity is a very serious problem, yet dangerously under-recognized (3). It was found that childhood obesity is a predictor of obesity and metabolic disorder in adulthood (4); therefore, it is of vital importance to control adult obesity at the root. According to Friedemann et al. (5) obese children share the same increase in risk as adults in developing comorbidities, such as hypertension, diabetes, and dyslipidemia. They are also more likely to develop psychosocial disorders as well as low self-esteem. (6)

The cause of childhood obesity is multifactorial. It includes behavioural factors, such as low levels of physical activity, poor nutrition, as well as environmental factors (7-9). It has also been noted that gestational diabetes and an early cessation or a complete lack of breastfeeding can increase the risk of developing obesity in children $(10,11)$. Genetic factors have also been implicated as studies suggest that familial transmission of adiposity can reach up to $50 \%(12)$.

A factor often overlooked, but which nevertheless plays a definitive role in children's weight, eating habits and physical activity, is maternal perception of overweight and obesity and its influences (13). A number of studies have compared mothers' assessment of their child's weight with the child's body mass index (BMI). These studies concluded that as few as $32 \%$ and as many as $90 \%$ of mothers underestimate their children's weight as De La O et al. (14) summarized in their study. This demonstrates that there is a discrepancy between mother's perception and actual weight status of their children, which gives rise to the question: If mothers are not able to identify their child's obesity, how will they realize that the home environment they are creating is inadvertently unhealthy?

Obesity has most notably demonstrated an exponential increase in the Middle East, and in Kuwait there is a marked increase in the prevalence of childhood obesity $(1,15)$. There is a longstanding cultural norm among the Kuwaiti population that "a fat baby is a healthy baby". In our study, we aimed to explore the maternal perception of the child's current BMI status and estimate the prevalence of childhood obesity in Kuwait. 


\section{Methods}

A nationwide cross-sectional study was conducted in Kuwaiti public schools with a sample size of 2253 children using a multi-stage, gender-stratified randomized cluster-sampling scheme. There are 214 elementary public schools distributed across all six governorates in Kuwait, which are all unisex (i.e. all-male or all-female only). A list of schools compiled in the Ministry of Education website (http://www.moe.edu.kw) was used to sample the schools from all parts of Kuwait, both urban and semi-urban. The stratified multi-stage sampling scheme was conducted by first selecting the schools according to governorate and sex after assigning each school a number and then including all the classes as the second stage in this study, since we aimed to include all eligible students in each of the selected schools as clusters in our sampling scheme.

The schools to be included in this survey were randomly selected using an online random number generator (http://www.random.org). We selected one allmale and one all-female school randomly from each of the six governorates to be included in this study, resulting in a total of 12 schools included in this study. In these randomly selected schools all students aged 6 to 8 years and in grades one to three were included in this study as a cluster sample. We excluded students above the age of 8 years to rule out the effect of puberty. Also, choosing 6 years and above makes it more convenient because the average age of students starting primary school is 6 years in Kuwait. Data were obtained from nurse's records of height and weight and perception were assessed through a self-administered questionnaire.

\section{Research instrument for the study consisted of two major parts.}

\section{Part A: Anthropometric data}

Height and weight measured within three months prior to the date of data collection were obtained from nurses' records in school with the approval of the Ministry of Health. The nurses were trained to use the standardized scales issued by the Ministry of Health.

\section{Part B: Maternal questionnaire}

A 29-item questionnaire was employed in this study, in which mothers are mainly asked to classify their perception of their children's weight in a written form using a five point Likert scale ranging from "extremely underweight" to "extremely overweight". Maternal perception questions that were used in this study were based on validated tools used by previous researchers. $(14,16)$

Other items included were as follows:

1. Demographic and socioeconomic variables: age, nationality, occupation, education, income, and marital status.

2. Questions regarding the child: date of birth, birth weight, sibling number, birth order, breastfeeding and length of breastfeeding, and child comorbidities.
3. Questions regarding maternal perception: mothers and grandparents' perceptions.

4. Questions regarding child's nutrition and physical activity: amount of meals, type of food consumed, types of physical activity, video game and TV time.

5. Maternal anthropometry: mother's height and weight, self-perception of their body weight.

\section{Sample size determination}

As the main aim of this study was to evaluate the maternal perception associated with child overweight and obesity status, we computed the sample size required for an odds ratio (OR) of 1.5 or greater to be statistically significant. We found a sample size of 1151 would be sufficient for any OR of 1.5 or greater to be statistically significant at an alpha level of $5 \%$ with a power of $90 \%$. However, based on previous studies, we estimated that the response rate from the mothers would not exceed 50\%. This meant we would have to approach at least 2302 children to have 1151 sample required. We also computed that with the sample size of 1151 , we could quantify the $95 \%$ confidence interval of the prevalence of obesity and overweight to be in the range of $\pm 4 \%$. We used PASS12 to compute the sample size required (17).

\section{Statistical analysis}

Data were analysed using SPSS for Windows (version 23) (18). Based on the date of birth of the child, ages were calculated as well as the BMI of the children using their anthropometry data. Using Centres for Disease Control and Prevention (CDC) (19) and WHO age and gender specific cut-offs for BMI (20), the children were classified as underweight $(<5$ th percentile), normal $(\geq 5$ th to $<85$ th percentile), overweight ( $\geq 85$ th to $<95$ th percentile), and obese ( $\geq 95$ th percentile). We used two cut-off points so that results can be interpreted in different meta-analysis studies that use either CDC or WHO (Table 1). For the prevalence of each BMI category, 95\% confidence interval (CI) was also calculated. All bivariate and multivariate analyses used the CDC based classification in this study. This study utilized a multi-stage sampling scheme and as such intra-class correlations (ICC) of BMI of children nested within schools were computed to assess if the data could be analysed without taking the cluster structure into consideration.

Statistical analyses focused on comparing the child's BMI category with their mother's perception about their child's weight status (from extremely underweight to extremely overweight). In the univariate analysis, chisquare (for nominal variables) and chi-square for trend (for ordinal variables) were used to test if there was any statistically significant association between maternal underestimation (versus correct estimation) of their child's weight status and maternal characteristics. Underweight children were excluded from this analysis since their weight cannot be further underestimated. In addition, multivariate logistic regression with stepwise variable method was employed to assess which of the 
Table 1: Age and sex specific cut-offs for BMI of children classified according to Centers for Disease Control and Prevention (CDC) and World Health Organization (WHO)

\begin{tabular}{|c|c|c|c|c|c|c|c|c|c|c|c|c|}
\hline \multirow[t]{4}{*}{ Percentile } & \multicolumn{6}{|c|}{ CDC } & \multicolumn{6}{|c|}{ WHO } \\
\hline & \multicolumn{3}{|c|}{ Boys } & \multicolumn{3}{|c|}{ Girls } & \multicolumn{3}{|c|}{ Boys } & \multicolumn{3}{|c|}{ Girls } \\
\hline & \multicolumn{6}{|c|}{ Age } & \multicolumn{6}{|c|}{ Age } \\
\hline & 6 & 7 & 8 & 6 & 7 & 8 & 6 & 7 & 8 & 6 & 7 & 8 \\
\hline 5th & 13.7 & 13.7 & 13.7 & 13.4 & 13.4 & 13.5 & 13.4 & 13.6 & 13.8 & 13.1 & 13.2 & 13.4 \\
\hline $85^{\text {th }}$ & 17.0 & 17.4 & 17.9 & 17.0 & 17.6 & 18.3 & 16.9 & $17 \cdot 3$ & 17.7 & 17.2 & 17.6 & 18.1 \\
\hline 95th & 18.4 & 19.1 & 20.0 & 18.8 & 19.6 & 20.6 & 18.0 & 18.5 & 19.1 & 18.6 & 19.1 & 19.8 \\
\hline
\end{tabular}

maternal characteristics were independently associated with their underestimation.

\section{Ethical approval}

This study was conducted according to the guidelines laid down in the Declaration of Helsinki and all procedures involving human subjects were approved by the Faculty of Medicine Ethics Committee in Kuwait University and the Ministry of Education and the Ministry of Health of Kuwait. Written informed consent was obtained from all subjects.

\section{Results}

The total number of elementary school students enrolled in the schools randomly selected for this study in Kuwait was 2553. Of this, complete anthropometric data were available on 2253 children. After restricting the age to those between 6 to 8 year olds, the sample size reduced to 2208 (831 males and 1377 females). Thus, $86 \%$ of all children in the study population were included in the analyses for the calculation of obesity prevalence. However, the response rate of the maternal perception survey was only $39 \%$ despite repeated reminders.

A total of 1002 records with complete BMI data on children were linked to their maternal perception data. In order to ascertain if the lack of participation was not associated with the child's BMI levels, the weight status of children whom mothers participated were compared against those who did not; there were no statistically significant differences between the child's weightstatuses of participating mothers compared to those that did not participate $(P=0.747)$. ICC for BMI was $0.06,-0.02$ and 0.002 for those aged 6,7 and 8 year olds, respectively. In our view, such lower ICC provides sufficient justification for the analyses of data at the individual child level, safely ignoring the nested structure by schools for the purpose of data analyses.

The prevalence of overweight and obese children combined was $40.9 \%$ as per WHO cut-off values and $39.7 \%$ as per CDC categorizations (Table 2). The differences in classification of the children based on WHO compared to $\mathrm{CDC}$ were minimal from a clinical point of view. The rest of the analyses were carried out based on WHO classifications.

The prevalence of obesity and overweight combined, among females was $41.5 \%(95 \% \mathrm{CI}=39.4-43.5)$, whereas it was $36.7 \%(95 \% \mathrm{CI}=34.6-38.7)$ among male children $(P$ $=0.024)$. The main objective of this study was to assess maternal perception of their child's weight status, since it is hypothesized here that maternal attitude plays a major role in the body weight of young children in Kuwait, given that these younger children are under maternal control. Maternal perception and the child's actual weight status are summarized in Figure 1.

It is also hypothesized that those mothers who underestimate their child's BMI could be associated with their socio-demographic characteristics such as age, income, and educational levels as well as their own BMI. Although a number of socio-demographic variables such as age, nationality, income, occupational status and educational level were found to be associated with maternal underestimation in univariate analyses, a stepwise multivariate regression models showed only nationality to be independently associated with it (Table 3). For maternal underestimation, the outcome variable in these analyses were considered when the mothers thought that their child was of normal weight,

\begin{tabular}{|c|c|c|c|c|c|}
\hline & \multicolumn{2}{|c|}{ CDC } & \multicolumn{2}{|c|}{ WHO } & \multirow[t]{2}{*}{$P$-value } \\
\hline & $\mathbf{N}$ & (\%) & $\mathbf{N}$ & $\%$ & \\
\hline Underweight & 124 & (5.6) & 96 & (4.3) & 0.049 \\
\hline Normal & 1207 & $(54.7)$ & 1211 & $(54.8)$ & 0.947 \\
\hline Overweight & 335 & $(15.2)$ & 297 & (13.5) & 0.107 \\
\hline Obese & 542 & (24.5) & 604 & (27.4) & 0.028 \\
\hline Total & 2208 & 100.0 & 2208 & 100.0 & \\
\hline
\end{tabular}




\begin{tabular}{|c|c|c|c|}
\hline Parental characteristics & $\begin{array}{c}\text { Total } \\
\mathbf{N}\end{array}$ & $\begin{array}{c}\text { Maternal underestimation } \\
(\%)\end{array}$ & P-value \\
\hline Parental age & & & 0.018 \\
\hline $25-35$ & 459 & $(50.1)$ & \\
\hline $36-45$ & 355 & $(53.8)$ & \\
\hline$>45$ & 76 & $(65.8)$ & \\
\hline Nationality & & & $<0.001$ \\
\hline Kuwaiti & 724 & $(50.4)$ & \\
\hline Non-Kuwaiti & 222 & $(64.4)$ & \\
\hline Occupational status & & & 0.025 \\
\hline Retired & 40 & $(62.5)$ & \\
\hline Never worked & 292 & $(59.2)$ & \\
\hline Currently working & 616 & $(50.5)$ & \\
\hline Educational status & & & 0.034 \\
\hline Middle school or below & 139 & (59.0) & \\
\hline High school & 203 & $(56.7)$ & \\
\hline Diploma & 226 & (54.9) & \\
\hline University & 351 & $(49.6)$ & \\
\hline Marital status & & & 0.728 \\
\hline Married & 844 & (53.6) & \\
\hline Divorced & 70 & $(55.7)$ & \\
\hline Income & & & 0.055 \\
\hline$<500 \mathrm{KD}^{2}$ & 62 & $(56.5)$ & \\
\hline 501-1000 KD & 281 & (58.7) & \\
\hline 1001-1500 KD & 244 & $(52.9)$ & \\
\hline $1501-2000 \mathrm{KD}$ & 176 & $(46.6)$ & \\
\hline$>2000 \mathrm{KD}$ & 169 & $(52.1)$ & \\
\hline Parents' weight status & & & 0.751 \\
\hline Normal weight & 191 & $(50.8)$ & \\
\hline Overweight/Obese & 491 & $(52.1)$ & \\
\hline Variable & \multicolumn{2}{|c|}{ Multivariate stepwise logistic regression ${ }^{1}$} & P-value \\
\hline \multicolumn{4}{|c|}{ Parental underestimation } \\
\hline \multicolumn{4}{|l|}{ Nationality } \\
\hline Kuwaiti & \multicolumn{2}{|c|}{$0.5(0.3-0.7)$} & 0.002 \\
\hline Non-Kuwaiti & \multicolumn{2}{|c|}{ Reference } & \\
\hline
\end{tabular}

${ }^{1}$ All maternal characteristics listed in this table were included in the multivariate regression model and only nationality was retained by the stepwise selection process. ${ }^{2} \mathrm{KD}=\mathrm{US} \$ 3.29$

underweight, or extremely underweight, when in fact they were overweight/obese. If the child's weight status was normal and the mother felt that her child was underweight or extremely underweight was also taken to be underestimation.

\section{Discussion}

Kuwait has been described in the media as one of the most obese countries in the world (21). According to an earlier WHO report, Kuwait ranked as the 13th most obese country globally $(2,21)$ and with regard to childhood obesity, Kuwait is also considered one of the highest ranking countries. In this study we found the prevalence of childhood overweight and obesity in children aged 6 to 8 years to be approximately $40 \%$.

There is paucity of data on the prevalence of obesity among pre-pubertal children in the Gulf region. According to a former review article comparing childhood obesity among Middle Eastern countries (22), it was clear that Kuwait - in comparison with the prevalence determined in this study - was easily among the highest in terms of childhood obesity. However, published reports from other countries reported a considerably lower prevalence than 40\%; for instance, the prevalence of childhood overweight and obesity in Germany was estimated to 
Figure 1: Actual weight of the children versus the parental perception of their child's weight

Child's weight

Normal weight

Overweight

$0 \%$

$20 \%$

$40 \%$

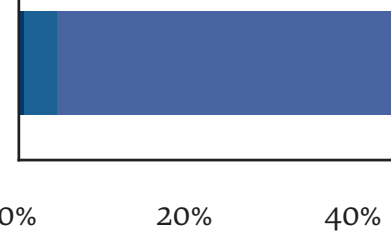

Parental preceptions of their child's weight (\%)

- Extremely underweight

Underweight

Normal

Overweight

Extremely overweight be $18.3 \%,(23)$ and in France it was $15.2 \%(24)$. The higher prevalence noted in this study is alarming and demands research on the determinants of childhood obesity in Kuwait.

It is considered here that the child's sex might play a role in the development of overweight or obesity. Females appeared to be more overweight or obese (41.5\%) than boys, which is similar to studies conducted in the United Arab Emirates, where it was found that the female population was more overweight or obese than male counterparts. (25) Moreover, studies conducted in the United States of America showed a similar pattern (1). This highlights the higher risk among females across different societies, regardless of demographic and cultural factors. At the level of adult obesity, more females appear to be obese in Kuwait (26). If childhood obesity is extrapolating into adulthood, then tackling it is tantamount to reducing the burden of disease that manifests in adulthood.

More importantly, our findings ascertained that the effect of parental perception is paramount to the body weight levels of children in Kuwait. Using a five-point Likert scale ranging from "extremely underweight", "underweight", "normal", "overweight", to "extremely overweight", we asked mothers to classify their perception of their child's weight. It became apparent that the rate of misperception on the mother's part exceeded that of any correct perception of their child's weight status. $92.2 \%$ of mothers with overweight children underestimated the true weight, with $77.9 \%$ considering them of normal weight and $14.3 \%$ underweight. Furthermore, $45.4 \%$ of mothers classified obese children as having normal weight and $4.0 \%$ as being underweight. It was also interesting to note that $39.8 \%$ of mothers also tended to consider their child to be underweight in spite of their child having normal weight (Figure 1). This supports suspicions that there appears to be an obvious distortion in Kuwaitis' perception of what constitutes a "healthy" physique.

Given that childhood obesity is linked to a plethora of diseases and is highly linked to the development of adult obesity, maternal perception can be used as a predictor of childhood obesity, as demonstrated in this study. Unfortunately, there is a paucity of studies related to this specific issue in Kuwait and the Gulf Arab region, which is experiencing higher level of obesity and related chronic diseases. The public health implications that can be addressed through the issue of maternal misperception and their active role in changing their child's weight status are innumerable. If we tackle childhood obesity at its root we can effectively reduce the rate of adult obesity with all its associated comorbidities such as heart disease, hypertension, and diabetes. This is vital as studies have quantified the risk of adult disease associated with obesity. For instance, the age-adjusted relative risk (RR (confidence interval [CI])) for cardiovascular disease increased among those who were obese in men (1.46 [1.20 -1.77]) and in women (1.64 [1.37-1.98]) (27).

\section{Limitations}

There are a number of limitations to this study that must be acknowledged. BMI is often criticized as an imperfect measure of adiposity, yet it is still one of the best meas- 
ures available for population based assessments. Furthermore, the weight and height of the mothers as well as breast feeding history were all self-reported, with potential for a high risk of bias.

\section{Conclusion}

We found a very high prevalence (40\%) of obesity and overweight in 6 to 8-year-old elementary school children in Kuwait, and $77.9 \%$ of overweight and $45.4 \%$ of obese children were perceived by their mothers to have normal body weights. Additionally, 39.8\% of children with healthy body weight were judged by their mothers to be underweight. As such, we found that a large proportion of mothers underestimated their child's true weight status, which could negate all public health intervention on childhood obesity. If a mother misclassifies their overweight child as being of "healthy" or "normal weight" then it is expected that they will be hesitant to change their child's weight. For this reason, we believe that correct maternal perception is paramount to tackling the issue of childhood obesity. This can only be achieved by proving to mothers that their perception of a healthy weight is incorrect and this misperception may lead to chronic and negative health implications later in the child's life.

\section{Acknowledgements}

The authors would like to thank the Ministry of Health and the Ministry of Education of Kuwait for their aid and support in this research. We would also like to thank all the nurses, principals and teachers who contributed to the data collection.

Funding: None.

Competing interests: None declared.

\section{Étude transversale de la perception maternelle de l'obésité des enfants âgés de 6 à 8 ans au Koweït}

\section{Résumé}

Contexte : L'obésité de l'enfant est en augmentation au Moyen-Orient.

Objectifs : La présente étude visait à déterminer la prévalence de l'obésité chez les enfants de six à huit ans et à étudier la perception du poids des enfants par les mères.

Méthodes : Une étude nationale des données concernant la taille et le poids a été réalisée à partir des dossiers des infirmières et les perceptions des mères ont été évaluées au moyen d'un questionnaire auto-administré. La taille de l'échantillon comprenait 2208 personnes ayant des mesures de l'indice de masse corporelle (IMC) et 1002 sujets ayant des données sur l'IMC et la perception des mères.

Résultats : La prévalence combinée du surpoids et de l'obésité de l'enfant était de 40,9\% selon les valeurs seuils de l'OMS et de 39,7\% selon les catégories établies par les Centers for Disease Control and Prevention (CDC). Nous avons également constaté que $77,9 \%$ des enfants en surpoids et $45,4 \%$ des enfants obèses étaient perçus par leur mère comme ayant un poids corporel normal. De plus, 39,8\% des enfants ayant un poids normal ont également été jugés par leur mère comme ayant un poids insuffisant.

Conclusions : La prévalence alarmante de l'obésité infantile chez les enfants koweïtiens, associée à la perception déformée par les mères de l'état pondéral réel de leur enfant, est une préoccupation grave qui nécessite une intervention de santé publique urgente.

$$
\begin{aligned}
& \text { السمنة وإدر اك الأمهات: دراسة مقطعية للأطفال الذين تتراوح أعحارهم بين ج وه سنوات في الكويت }
\end{aligned}
$$

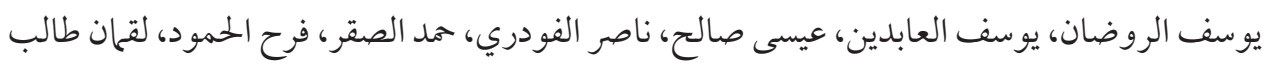

$$
\begin{aligned}
& \text { الخلاصة } \\
& \text { الخلفية: تعد سمنة الأطفال في ازدياد في الشرق الأوسط. } \\
& \text { الأهداف: هدفت هذه الدراسة إلى تحديد معدل انتشار السمنة بين الأطفال الذين تتراوح أعمارهم بين } 7 \text { وم سنوات، واستقصاء إدر اك الأمهات } \\
& \text { عن وزن الأطفال. }
\end{aligned}
$$

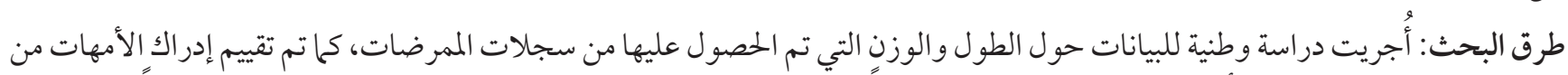

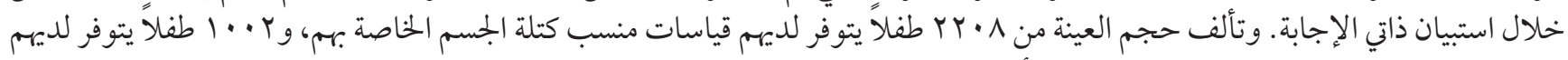

$$
\begin{aligned}
& \text { قياسات منسب كتلة الجسم الخاصة بهم وإدر اك الأمهات العهات }
\end{aligned}
$$




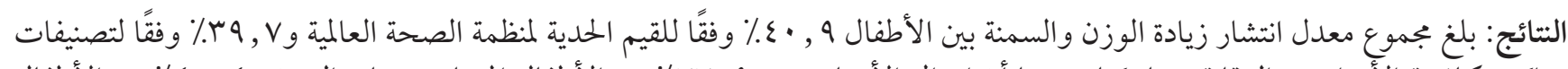

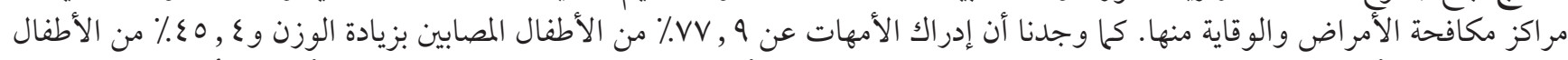

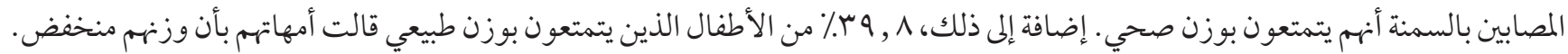

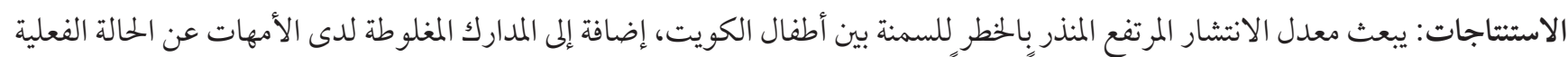

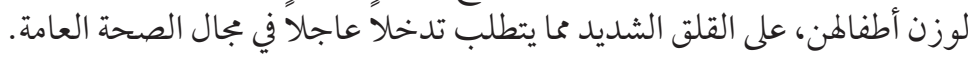

\section{References}

1. Ng M, Fleming T, Robinson M, Thomson B, Graetz N, Margono C, et al. Global, regional, and national prevalence of overweight and obesity in children and adults during 1980-2013: a systematic analysis for the Global Burden of Disease Study 2013. Lancet. 2014;384(9945):766-81. http://dx.doi.org/10.1016/So140-6736(14)60460-8

2. World Health Organization. Obesity and overweight: Fact sheet no. 311. Geneva: World Health Organization; 2015 (http://www. who.int/en/news-room/fact-sheets/detail/obesity-and-overweight).

3. Bass R, Eneli I. Severe childhood obesity: an under-recognised and growing health problem. Postgrad Med J. 2015 Nov;91(1081):639-45. http://dx.doi.org/10.1136/postgradmedj-2014-133033

4. Sun SS, Liang R, Huang TT, Daniels SR, Arslanian S, Liu K, et al. Childhood obesity predicts adult metabolic syndrome: the Fels Longitudinal Study. J Pediatr. 2008 Feb;152(2):191-200. http://dx.doi.org/10.1016/j.jpeds.2007.07.055

5. Friedemann C, Heneghan C, Mahtani K, Thompson M, Perera R, Ward AM. Cardiovascular disease risk in healthy children and its association with body mass index: Systematic review and meta-analysis. BMJ. 2012;345 sep25 2:e4759. http://dx.doi. org/10.1136/bmj.e4759

6. Dietz WH. Health consequences of obesity in youth: Childhood predictors of adult disease. Pediatrics. 1998 Mar;101(3 Pt 2):518-25.

7. Dowda M, Ainsworth BE, Addy CL, Saunders R, Riner W. Environmental influences, physical activity, and weight status in 8- to 16-year-olds. Arch Pediatr Adolesc Med. 2001;155(6):711-7. http://dx.doi.org/10.1001/archpedi.155.6.711

8. Malik AH, Akram Y, Shetty S, Malik SS, Yanchou Njike V. Impact of sugar-sweetened beverages on blood pressure. Am J Cardiol. 2014;113(9):1574-80. http://dx.doi.org/10.1016/j.amjcard.2014.01.437

9. Anderson SE, Whitaker RC. Household routines and obesity in us preschool-aged children. Pediatrics. 2010;125(3):420-8. http:// dx.doi.org/10.1542/peds.2009-0417

10. Kim SY, Sharma AJ, Callaghan WM. Gestational diabetes and childhood obesity: What is the link? Curr Opin Obstet Gynecol. 2012 Dec;24(6):376-81 http://dx.doi.org/10.1097/GCO.obo13e328359fof4

11. Ip S, Chung M, Raman G, Trikalinos TA, Lau J. A summary of the agency for healthcare research and quality's evidence report on breastfeeding in developed countries. Breastfeed Med. 2009;4(s1) Suppl 1:S17-30. http://dx.doi.org/10.1089/bfm.2009.0050

12. Nies VJM, Struik D, Wolfs MGM, Rensen SS. TUB gene expression in hypothalamus and adipose tissue and its association with obesity in humans. Int J Obes (Lond). 2018 Mar;42(3):376-383 http://dx.doi.org/10.1038/ijo.2017.214

13. Jaballas E, Clark-Ott D, Clasen C, Stolfi A, Urban M. Parents' perceptions of their children's weight, eating habits, and physical activities at home and at school. J Pediatr Health Care. 2011;25(5):294-301. http://dx.doi.org/10.1016/j.pedhc.2010.05.003

14. De La OA, Jordan KC, Ortiz K, Moyer-Mileur LJ, Stoddard G, Friedrichs M, et al. Do parents accurately perceive their child's weight status? J Pediatr Health Care. 2009;23(4):216-21. http://dx.doi.org/10.1016/j.pedhc.2007.12.014

15. Gehani AA, Al-Hinai AT, Zubaid M, Almahmeed W, Hasani MRM, Yusufali AH, et al. Association of risk factors with acute myocardial infarction in middle eastern countries: The interheart middle east study. Eur J Prev Cardiol. 2014;21(4):400-10. http:// dx.doi.org/10.1177/2047487312465525

16. Jeffery AN, Voss LD, Metcalf BS, Alba S, Wilkin TJ. Parents' awareness of overweight in themselves and their children: cross sectional study within a cohort (EarlyBird21). BMJ. 2005 Jan 1;330(7481):23-4. http://dx.doi.org/10.1136/bmj.38315.451539.F7

17. PASS 12. NCSS Statistical Software. (http://www.ncss.com).

18. Corp IBM. Released 2015. IBM SPSS Statistics for Windows, Version 23.0. Armonk, NY: IBM Corp.

19. Kuczmarski RJ, et al. 2000 CDC Growth Charts for the United States: methods and development. Vital Health Stat 11. 2002;11(246):1-190.

20. Wohlfahrt-Veje C, Tinggaard J, Winther K, Mouritsen A, Hagen CP, Mieritz MG, et al. Body fat throughout childhood in 2647 healthy Danish children: agreement of BMI, waist circumference, skinfolds with dual X-ray absorptiometry. Eur J Clin Nutr. 2014;68(6):664-70. http://dx.doi.org/10.1038/ejcn.2013.282

21. Bond A. Fattest countries in the world revealed: Extraordinary graphic charts the average body mass index of men and women in every country (with some surprising results) Daily Mail. 29 March 2013 (http://www.dailymail.co.uk/health/article-2301172/Fattest-countries-world-revealed-Extraordinary-graphic-charts-average-body-mass-index-men-women-country-surprising-results. html).

22. World Health Organization. Global database on body mass index: An interactive surveillance tool for monitoring nutrition transition. Geneva: World Health Organization; 2015 (http://www.who.int/nutrition/databases/bmi/en/). 
23. Kurth BM, Schaffrath Rosario A. Die Verbreitung von Übergewicht und Adipositas bei Kindern und Jugendlichen in Deutschland. Results of the German health interview and examination survey for children and adolescents (kiggs). Bundesgesundheitsblatt Gesundheitsforschung Gesundheitsschutz. 2007;50(5-6):736-43. http://dx.doi.org/10.1007/s00103-007-0235-5

24. Lioret S, Maire B, Volatier JL, Charles M-A. Child overweight in france and its relationship with physical activity, sedentary behaviour and socioeconomic status. Eur J Clin Nutr. 2007;61(4):509-16. http://dx.doi.org/10.1038/sj.ejcn.1602538

25. Al-Haddad FH, Little BB, Abdul Ghafoor AG. Childhood obesity in united arab emirates schoolchildren: A national study. Ann Hum Biol. 2005;32(1):72-9. http://dx.doi.org/10.1080/03014460400027425

26. Zaghloul S, Al-Hooti SN, Al-Hamad N, Al-Zenki S, Alomirah H, Alayan I, et al. Evidence for nutrition transition in kuwait: Over-consumption of macronutrients and obesity. Public Health Nutr. 2013;16(04):596-607. http://dx.doi.org/10.1017/ S1368980012003941

27. Wilson PW, D'Agostino RB, Sullivan L, Parise H, Kannel WB. Overweight and obesity as determinants of cardiovascular risk: The framingham experience. Arch Intern Med. 2002;162(16):1867-72. http://dx.doi.org/10.1001/archinte.162.16.1867 